\title{
HIPÓTESES INCONSTITUCIONAIS NA INCIDÊNCIA DE DIREITOS POLÍTICOS NEGATIVOS AOS MILITARES
}

\author{
UNCONSTITUTIONAL HYPOTHESES IN THE INCIDENCE OF \\ NEGATIVE POLITICAL RIGHTS TO MILITARY
}

\begin{abstract}
“Queremos buscar a verdade, não importa aonde ela nos leve. Mas para encontrá-la, precisaremos tanto de imaginação quanto de ceticismo. Não teremos medo de fazer especulações, mas teremos o cuidado de distinguir a especulação do fato".

Carl Sagan
\end{abstract}

Marcos César Botelho ${ }^{1}$

Gabriel Vieira Terenzi ${ }^{2}$

\section{RESUMO}

O presente trabalho tem como objetivo analisar o tratamento conferido pelo regramento legal brasileiro aos membros das forças armadas, tanto da tropa quando do oficialato, no intento de responder aos seguintes questionamentos: as disposições que regulamentam a participação política dos militares são inconstitucionais? Se sim, em que pontos, e sob quais parâmetros? Para tanto, fora adotada uma metodologia dedutiva. Diante do tema, estabelecer-se-ão as modalidades da incidência de direitos políticos negativos - aqueles que limitam o exercício da participação política - especialmente aos militares -, bem como suas respectivas características, razões e fundamentos. A partir desses institutos, passar-se-á a uma avaliação de sua compatibilidade com o texto constitucional. Optou-se, conscientemente, por avaliar a constitucionalidade mediante as posições consolidadas pela jurisprudência e pela academia

\footnotetext{
${ }^{1}$ Doutor em Direito Constitucional no programa da Instituição Toledo de Ensino/Bauru-SP (2011). Mestre em Direito Constitucional pelo Instituto Brasiliense de Direito Público (2008). Membro da Associação Nacional de Advogados(as) do Direito Digital (ANADD). Membro da Associação Nacional dos Profissionais de Privacidade de Dados (ANPPD). É professor adjunto vinculado ao programa de mestrado em ciências jurídicas na Universidade Estadual do Norte do Paraná (UENP). Foi Advogado da União - Advocacia-Geral da União, tendo atuado na Procuradoria Seccional da União em Campinas/SP, na Coordenação de Propositura de Ações Não Pró-ativas e de Acompanhamento de Ações Penais, Coordenação de Patrimônio Público e Coordenação Trabalhista na Procuradoria-Regional da União da $3^{\text {a }}$ Região SP/MS e na Procuradoria-Seccional da União em Marília/SP. Foi Coordenador-Geral de Atos Normativos, Coordenador-Geral de Contencioso Judicial e Coordenador-Geral de Exame de Procedimentos Administrativos, todos na Consultoria Jurídica do Ministério da Defesa.

2 Advogado. Mestrando em Ciência Jurídica na linha de pesquisa Função Política do Direito pela UENP Universidade Estadual do Norte do Paraná. Graduado em Direito pelo Centro Universitário Toledo de Araçatuba. Ex-estagiário do Escritório de Assistência Judiciária Gratuita "Dr. Maurício de Toledo; da 146a Zona Eleitoral do Tribunal Regional Eleitoral e do Ministério Público do Estado de São Paulo. Membro do quadro de pesquisadores dos Grupos de Pesquisa Sistema Interamericano de Direitos Humanos; Direito Internacional Contemporâneo; Jurisprudência de Direitos Fundamentais, todos vinculados ao Centro Universitário Toledo; e do Grupo de Pesquisa Ideologia do Estado e Estratégias Repressivas, vinculado à Universidade Estadual do Norte do Paraná. Pesquisador e escritor.
} 
nacionais. Assim, não será verificada a adequação constitucional segundo teorias pouco recepcionadas no cenário nacional, como aquela da inconstitucionalidade de norma proveniente do poder constituinte originário. Desse modo, com o cotejo dos parâmetros estabelecidos, conclui-se pela constitucionalidade do impedimento ao alistamento do conscrito, do regime sui generis na candidatura do oficial e da suspensão dos direitos políticos daquele que deixa de cumprir serviço alternativo ao serviço militar obrigatório. Conclui-se, noutro giro, pela inconstitucionalidade de proibir-se ao conscrito já alistado o voto, de restringir a candidatura do condenado por indignidade militar, e de privar de direitos políticos aquele que não cumpriu serviço alternativo e ultrapassou quarenta e cinco anos de idade.

\title{
PALAVRAS-CHAVE:
}

Direitos Políticos; Inconstitucionalidade; Militares.

\begin{abstract}
The present paper aims to analyze the treatment given by the Brazilian legal rule to members of the armed forces, both from the troops and from the officers, in an attempt to answer the following questions: are the provisions that regulate the political participation of the military unconstitutional? If so, at what points, and under what parameters? For that, a deductive methodology had been adopted. In view of the theme, the modalities of the incidence of negative political rights - those that limit the exercise of political participation - especially to the military - will be established, as well as their respective characteristics, reasons and foundations. From these institutes, an assessment of their compatibility with the constitutional text will be carried out. It was consciously chosen to evaluate constitutionality through the positions consolidated by national jurisprudence and academia. Thus, it will not be verified the constitutional adequacy according to theories little received in the national scene, such as that of the unconstitutionality of a rule from the original constituent power. Thus, with the comparison of the established parameters, it concludes by the constitutionality of the impediment to the conscription of the conscript, of the sui generis regime in the candidacy of the officer and of the suspension of the political rights of the one who fails to perform alternative service to the mandatory military service. It concludes, in another round, by the unconstitutionality of prohibiting the conscript already listed from voting, of restricting the candidacy of the convict for military indignity, and of depriving of political rights the one who has not fulfilled alternative service and has exceeded forty-five years of age.
\end{abstract}

\section{KEYWORDS:}

Political Rights; Unconstitutionality; Military. 


\section{INTRODUÇÃO}

Não é de se espantar que haja uma tensão implícita ao se cogitar a participação política dos militares. Conforme ensina a história brasileira, passou o país por diversas crises e rupturas democráticas, na maioria das quais desencadeou-se, inclusive, processos constituintes, e em todas estas o papel das forças armadas foi de protagonismo.

Desde a primeira Constituição brasileira, outorgada em 1824 após a dissolução forçada da assembleia constituinte, passando pelo golpe que pôs fim à monarquia, pela ditadura varguista, e, como não poderia deixar de se mencionar, os longos vinte e um anos de ditadura militar inaugurada em 1964, estabeleceram-se sístoles e diástoles na democracia brasileira, as quais somente vieram a se encerrar (espera-se que definitivamente) pela Carta de Outubro de 1988.

Algumas características próprias da caserna, como a rígida estrutura de obediência hierárquica, bem como um certo grau de diminuta transparência inerente a algumas tomadas de decisões militares podem contribuir para a percepção de descompasso na participação dos membros das forças armadas em deliberações eleitorais, cuja natureza competitiva e dialética parece apartada.

Igualmente, dada a própria função bélica e o constrangedor histórico ainda recente do período dos anos de chumbo, há em alguma medida um desconforto na democracia com os parâmetros, limites e possibilidades de atuação dos militares no ambiente político.

Por sua vez, também não se pode, com base nesse desconforto, cogitar-se um apartamento entre aquela classe e a efetiva participação eleitoral, até porque não foi essa a previsão adotada pela Constituição. Com efeito, a Lei Maior, garantiu aquela participação por membro dos fardados, não olvidando, ao mesmo tempo, da imposição de situações jurídicas distintas.

Essas distinções se aprofundam quando considerado que a seara dos direitos políticos é aparentemente pouco densificada e compreendida pela comunidade jurídica brasileira, fruto esse, inclusive, de normas constitucionais com infeliz redação no que tange à matéria. 
Assim que, a fim de que seja superado aquele lamentável histórico de desavenças democráticas, as classes militares precisam, antes de apático desinteresse por parte da academia, e menos ainda de atrasado preconceito, de compreensão aberta e crítica por arte do pensamento constitucional.

Ou seja, há de se formular compreensões sobre o tratamento destinado pelo bloco de constitucionalidade pátrio aos membros das forças armadas, e essas compreensões devem prever não somente as proibições e balizas como também as garantias e privilégios destinados à tropa no tema democrático.

O presente trabalho, consciente desse contexto, pretende verificar a compatibilidade com a constituição das previsões normativas atuais que impõem limitação ao aproveitamento dos direitos políticos por parte dos militares.

Utilizando-se de metodologia dedutiva, passa-se a verificar, por primeiro, as modalidades de incidência de negativa ao feixe dos direitos políticos, para, a partir de então, localizar nessas espécies as causas que repercutem aos membros das falanges militares. Finalmente, verificar-se-á a constitucionalidade desses reflexos.

\section{UMA BREVE CONCEITUAÇÃO A RESPEITO DOS DIREITOS POLÍTICOS}

Para os fins do presente trabalho, adotar-se-á a definição de direitos políticos como aquele conjunto de regras que garantem, restringem e regulamentam aos cidadãos o exercício da soberania popular, manifestada especialmente pela participação no processo político.

Desse conceito introdutório, pode-se passar a delimitar o tema. Parece interessante afirmar serem estes "as prerrogativas, os atributos, faculdades ou poder de intervenção dos cidadãos ativos no governo de seu país, intervenção direta ou só indireta, mais ou menos ampla, segundo a intensidade do gozo desses direitos" (BUENO, 2002, p. 549).

Se esse ramo jurídico se destina, em suma, a assegurar a efetivação da soberania popular, deve ser, ao menos em tese, compreendido esse ideário. Conforme expõe Marcelo Forneiro 
Machado (2009, p. 119) "a teoria da soberania popular concebe a titularidade da soberania como pertencendo a todos os componentes do povo, atribuindo a cada cidadão uma parcela da soberania".

Segundo o mesmo autor a grande inovação do período da modernidade (séculos XVII e XVIII), marco a partir do qual o que hoje se concebe como soberania popular começa a ser delineado, é o deslocamento dessa prerrogativa da figura do soberano para o povo, "que não aliena a soberania a um governante, mas constitui comissários que executam as leis" (MACHADO, 2009, p. 126).

Por outro lado, os direitos políticos em sua concepção atual se revestem de mais amplitude do que essa mera garantia à consentir. Há, para além dessa liberdade negativa, o interesse de que aos cidadãos seja concedido uma real e efetiva possibilidade de participação nos processos de tomada de decisões políticas, especialmente sufragando a respeito de quem ocupará os cargos eletivos, mas também optando, nos pleitos, pelos rumos que devem ser tomados pela nação (KAZMIERCZAK; ALVES, 2013, p. 418).

Pierre Rosanvallon corrobora com esse locus da soberania nas decisões coletivas ao discorrer sobre o que chama de descentralização da democracia, o que, in verbis depende de um "tissue of relationships between government and society. [...] the social appropriation of political power"3 (ROSANVALLON, 2011, p. 9).

Portanto, pode se afirmar que os direitos políticos, em relação à soberania popular, possuem a dupla função de resguardar a imprescindível garantia de que cabe aos governados decidir a respeito dos seus governantes, e ainda permitir que aqueles interfiram, em alguma medida, na atuação destes.

"Em alguma medida", porque, como bem salienta Manin (2002, p. 237), "the absence of imperative mandates, legally binding pledges, and discretionary recall, gives representatives

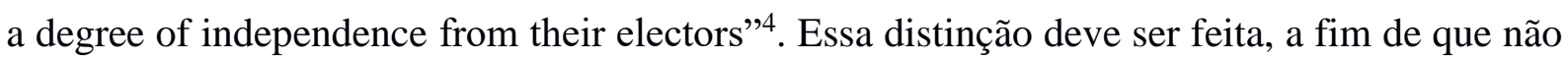

\footnotetext{
${ }^{3}$ Em tradução livre: "tecido de relações entre governo e sociedade [...] a apropriação social do poder político".

${ }^{4}$ Em tradução livre: "a ausência de mandatos imperativos, pleitos legalmente vinculantes e revogação discricionária dá aos representantes um grau de independência de seus eleitores".
} 
se confunda a democracia representativa atual (calcada nos direitos políticos como veículos da soberania popular) com um regime fundamentalmente plebiscitário.

Diante dessa concepção, sendo os direitos políticos responsáveis por instrumentalizar a soberania popular, pode ser o ramo agora classificado como "direitos públicos subjetivos [de cuja condição] emerge o poder de participação direta ou indireta, na condução da coisa pública" (RAMAYANA, 2018, p. 1).

Não se pode deixar de notar serem estes direitos fundamentais, também integrantes do ramo dos direitos humanos. Quanto a estes, desnecessário mencionar que se aplicam universalmente a todos os indivíduos, não por força da concessão estatal ou em razão de um pacto inter-partes, mas sim pela própria condição inerente à cada ser da espécie humana que faz jus a uma dignidade essencial mínima, em parâmetros historicamente consagrados.

Para os adeptos dessa taxonomia, tais direitos vêm sendo subdivididos em gerações, cada qual "foi associada, na Conferência proferida por Vasak, a um dos componentes do dístico da Revolução Francesa: 'liberté, egalité et fraternité' (liberdade, igualdade e fraternidade)" (RAMOS, 2017, p. 53).

Como direitos fundamentais, os mesmos encontram previsão na Constituição, notadamente no art. 14. Nesse sentido, preveem ainda direitos políticos diversos diplomas legislativos infraconstitucionais, tais como o Código Eleitoral (lei $n^{\circ} 4.737 / 1965$ ); a Lei das Eleições (lei n ${ }^{\circ}$ 9.504/1997); Lei dos Partidos Políticos (lei $n^{\circ}$ 9.096/1995); Lei das Inelegibilidades (lei complementar $n^{\circ} 64 / 1990$ ), dentre outros.

Finalmente, por serem, como se apontou, direitos humanos, figuram os direitos políticos nas principais declarações internacionais quanto ao tema (GOMES, 2017, p. 33), tais como o Pacto Internacional sobre os Direitos Civis e Políticos (1948) e a Convenção Americana de Direitos Humanos (1969).

É importante de se destacar, por oportuno, que nosso ordenamento confere regramento distinto às duas dimensões dos direitos políticos: o seu gozo e seu exercício. Ruy Barbosa elucidou brilhantemente a celeuma, de maneira sucinta, estabelecendo o gozo como capacidade potencial, e o exercício como capacidade atual (BARBOSA, 1971, p. 47). 
Daí se extrai a caracterização que o presente trabalho passa a adotar, segundo a qual aquele indivíduo que ainda nem ao menos preencheu as condições de alistabilidade possui tão somente direitos políticos latentes. Ao caracterizar-se como alistável passa a deles gozar, e, finalmente, uma vez alistado (ausentes causas outras de incidência negativa, como será abordado), exerce direitos políticos.

Evidentemente, pode-se gozar sem exercer esse feixe jurídico, mas é inconcebível que um cidadão exerça direitos políticos sem, anterior e concomitantemente, tê-los em capacidade potencial. Também importante de se destacar que, embora o gozo dos direitos políticos seja unitário, seu exercício é complexo, ou seja, engloba diversos direitos-deveres que podem ser parcialmente exercidos (ou não).

O mais relevante esclarecimento, para os fins do presente trabalho, envolve a definição concedida por José Afonso da Silva, segundo a qual, sendo os direitos políticos responsáveis por dotar as possibilidades de participação política, os mesmos podem ser concebidos em uma dimensão positiva (ao conceder essa participação) ou negativa (ao limitá-la). Conforme expõe o mestre, direitos políticos negativos "consistem no conjunto de regras que negam, ao cidadão, o direito de eleger, ou de ser eleito, ou de exercer atividade político partidária ou de exercer função pública" (SILVA, 2007, p. 348).

Como o presente texto encampa, os direitos políticos tem em sua aplicação eficácia sempre dual: ao se garantir, apenas a título de exemplo, o alistamento a partir dos 16 anos (como um direito político positivo), se está, automaticamente, fazendo incidir aos menores dessa faixa etária a vedação ao alistamento - um direito político negativo.

Por sua vez, se universal o sufrágio, como estabelece o artigo 14 da Carta, nem sempre idêntico é o tratamento conferido a distintos atores democráticos. Basta notar que os magistrados e membros do Ministério Público, por sua vez, suportam o ônus de se verem impedidos de participação partidária. Não há razão para que fosse diferente com os membros das forças armadas.

É desnecessário relembrar que o poder constituinte é indissolúvel do conceito de constituição (BERCOVICI, 2013, pp. 305-306), e, uma vez que aquele poder é uma manifestação fática e histórica, não se deve espantar que nos conturbados momentos de 
acirramento de tensão ou mesmo de aberta ruptura institucional aptos a desencadear o exercício constituinte, estejam os poderes militares a desempenhar um papel de destaque.

Já na primeira experiência constitucional brasileira as forças armadas (que à época, nem ao menos possuíam essa designação) desempenharam papel importante, antes mesmo da outorga. Com efeito, como relembram Eder de Carvalho e Carlos Gileno (2018, p. 16), no decorrer da assembleia constituinte em 1823 Dom Pedro I, com o intuito de garantir o fortalecimento do poder moderador, utilizou-se do respaldo militar para dissolver a assembleia, culminando na "Noite da Agonia", entre os dias 11 para 12 de novembro daquele ano.

Desde então inaugurou-se um movimento das casernas às urnas, repleto de diversas ocasiões de rompimentos democráticos. Como relembra Carlos Guilherme Mota (1995, p. 252), teve especial relevância nesse contexto a Guerra do Paraguai, conflito militar que envolveu o país homônimo, a Argentina e o Brasil, trazendo como efeito uma profunda mudança no Estado, com a "emergência ulterior do Exército como força organizada e ideologicamente marcada por idéias republicanas. Nascia então um novo tipo de oficial militar caracterizado por um autoritarismo progressista”.

O oficiliato, desde então, "passou a exercer força decisiva, aproveitando-se do prestígio ganho com o êxito obtido na Guerra [...], associado à influência exercida pela doutrina do positivismo" (VAINER, 2010, p. 167).

O período mais traumático a envolver a direta participação militar foi, todavia, sem dúvida alguma o lamentável interregno da ditadura militar, que vigorou durante 21 anos até em 1985 encerrar (espera-se que definitivamente) as sístoles e diástoles da democracia brasileira. Nesse período, afinal, "the casuistic manipulation of election law was not only woven into the fabric of the Brazilian authoritarian regime, it was its predominant political strategy"5 (BARBOSA, 2017, 147).

Esse quadro de grave atipicidade e violação às garantias de participação popular somente se remediaram com o texto da Carta de Outubro, momento no qual se estabeleceu a

\footnotetext{
${ }^{5}$ Em tradução livre: “a manipulação casuística da lei eleitoral foi não somente cosida no tecido do regime autoritário brasileiro, mas era sua estratégia política predominante”.
} 
hoje consagrada universalização da capacidade política, com o redescobrimento da democracia por parte dos cidadãos (LIMA, 2014).

\section{DIREITOS POLÍTICOS NEGATIVOS NA CONSTITUÇÃO DE 1988}

Como já se apontou, os direitos políticos podem ser positivos e negativos, quando, respectivamente, garantirem ou restringirem a possibilidade de gozo e exercício das prerrogativas de participação política.

É, por sua vez, perceptível a carência de profundidade das normas constitucionais (não somente atuais, como também dos textos primevos) ao tratar, de maneira específica e coordenada, os efeitos desse regramento, o que ficou evidente no tópico anterior.

Essa tendência, infelizmente, se repete na Carta de 1988. Impera um trato manifestamente confuso em relação aos direitos políticos, com a utilização da nomenclatura equivocada de alguns dos institutos, e, inclusive, a ausência de definição a respeito dos termos adotados e de sua abrangência.

Também por essa razão, almeja o presente trabalho, ainda que em linhas gerais, traçar contornos distintivos entre as hipóteses de incidência de direitos políticos negativos na constituição cidadã, bem como em relação ao alcance de seus efeitos. Pois bem.

A primeira distinção aqui adotada é a análise das espécies de incidência de direitos políticos negativos. Afinal, como já foi apontado no primeiro capítulo do presente texto, tal feixe jurídico é composto por dimensões distintas. Assim que, enquanto determinadas normas vertem somente sobre o exercício das garantias políticas, outros regramentos poderão afetar tanto o seu exercer quanto o seu gozar.

Segundo a nomenclatura pela qual os presentes autores passam a optar, podem se conceituar como impedimentos as hipóteses que barram o indivíduo de progredir nas suas prerrogativas políticas. Explica-se. Se, como visto, o sujeito passa de um detentor dessas garantias latentes, ao gozo e finalmente ao exercício do feixe jurídico, os impedimentos de 
direitos políticos impossibilitam que o cidadão passe a gozar, ou ainda obsta que aquele que já goza de direitos políticos passe a exercê-los.

A característica distintiva do impedimento, é, assim, a sua perspectiva prévia - são condições que se apresentam anteriormente e, justamente por persistirem, obstaculizam que o seu detentor passe a gozar ou a exercer direitos políticos.

Por sua vez, classificam-se como restrições as incidências negativas que limitam parcialmente o exercício dos direitos políticos. Ora, sendo predicado lógico que o gozo daquelas garantias é unitário, enquanto o seu exercício se coaduna com diversas condutas, algumas causas de direitos políticos negativos apenas afetarão parte dessas condutas.

As restrições se diferenciam dos impedimentos, já que neste isntituto, já abordado, o sujeito deixa de "progredir" - se não goza, não passa a gozar, se não exercer, não pode passar a exercer. Em se tratando de uma restrição, o sujeito estará, em tesa, no gozo dos direitos políticos, mas a incidência desta limitará parcialmente o seu exercício.

Finalmente, podem ser abordadas as privações, a última categoria de incidência de direitos políticos negativos. Será privado desse ramo jurídico aquele que tiver totalmente removida uma das dimensões. Uma das dimensões porque as privações podem tanto atingir o exercício quanto o gozo dos direitos políticos. A essas duas hipóteses, denominam-se, respetivamente, suspensão e perda.

A Constituição Federal, ao abordar as privações no artigo 15, adotou infeliz redação que, embora distinga os conceitos, e ainda estabeleça a vedação à cassação, não revela especificamente qual a natureza das exceções previstas pelos incisos do dispositivo. Vejamos:

\footnotetext{
Art. 15. É vedada a cassação de direitos políticos, cuja perda ou suspensão só se dará nos casos de:

I - cancelamento da naturalização por sentença transitada em julgado;

II - incapacidade civil absoluta;

III - condenação criminal transitada em julgado, enquanto durarem seus efeitos;

IV - recusa de cumprir obrigação a todos imposta ou prestação alternativa, nos termos do art. $5^{\circ}$, VIII;

V - improbidade administrativa, nos termos do art. $37, \S 4^{\circ}$.
}

Assim que, nos esforços de classificação e de apontamento de um panorama a respeito dos direitos políticos negativos, deve se entender a cassação, a perda, e a suspensão, todas como 
modalidades de privação, sendo certo que a primeira é inconstitucional, por vedação expressa, sendo as demais elencadas pelo artigo 15.

Já se apontou que a privação faz estabelecer-se a remoção dos direitos políticos. Assim que o instituto se diferencia do impedimento, em que não há regresso, ao contrário, deixando de haver progresso. Também diverso das hipóteses de restrição, pois as restrições aos direitos políticos limitam parcialmente o seu exercício, enquanto as privações limitam integralmente o exercício ou o gozo dos direitos políticos (lembrando-se, novamente, que caso seja privado o gozo, se tornará imediatamente inviável o exercício).

Dentro da espécie privação, podem-se passar a abordar suas subdivisões. Tanto a cassação quanto a perda se caracterizam por privações definitivas. O que as diferencia (tornando inconstitucional a cassação) é a possibilidade de reaquisição. Com efeito, perdidos os direitos políticos, resta, hipoteticamente, possível sua retomada, o que não ocorre com a cassação.

Por sua vez, a suspensão de direitos políticos é uma limitação integral ao seu exercício. Integral, afinal, por ser uma privação, já que caso fosse parcial integraria as restrições. Ademais, após o prazo da suspensão, o restabelecimento pleno do exercício dos direitos políticos privados é automático. No caso da perda, cabe ao que esta suporta promover atos de modo a restabelecerem-se o gozo e exercício dos quais se viu privado.

Conclui-se, desse modo, que a incidência de direitos políticos negativos pode se dar na forma de impedimentos, os quais impossibilitam a aquisição do gozo ou, no caso deste já existir, da capacidade de exercer o ramo; de restrições, que limitam parcialmente o exercício daqueles direitos; e na forma de privações, que proporcionam a remoção integral do gozo (perda) ou do exercício (suspensão), sendo também modalidade inconstitucional de privação a cassação - em que o perdimento dos direitos será irreversível.

Em nosso atual regramento, funcionam como impedimentos ao gozo a idade, a nacionalidade, e a impossibilidade de exprimir sua vontade. Afinal, o menor de dezesseis anos ainda não possui nem mesmo a alistabilidade, a teor do art. $14, \S 1^{\circ}$, da Carta, sendo que o mesmo se dá em relação ao estrangeiro e aquele que não é capaz de exprimir sua vontade. 
Note-se, mais uma vez, tratarem-se tais razões de impedimentos já que são condições prévias que, com sua subsistência, fazem incidir um direito político negativo - a negativa de condições de alistabilidade e consequente gozo de status civitatis.

Ponto interessante se relaciona com o incapaz de exprimir sua vontade. Segundo o art. 15, inciso II da Constituição Federal, há a possibilidade de perda ou suspensão (não identificada) no caso de incapacidade civil absoluta. Portanto, ab initio, esclareça-se que ao portador de deficiência subsiste o pleno gozo e exercício de suas potencialidades no campo político.

Assim, o artigo 85 do Estatuto da Pessoa com Deficiência (Lei 13.146/15) dispõe: "A curatela afetará tão somente os atos relacionados aos direitos de natureza patrimonial e negocial". Enquanto seu $\S 1^{\circ}$ baliza que “A definição da curatela não alcança o direito ao próprio corpo, à sexualidade, ao matrimônio, à privacidade, à educação, à saúde, ao trabalho e ao voto".

O Código Eleitoral, em seu art. 71, inciso II, confere inclusive ao juízo cível a responsabilidade de comunicação ao respectivo juízo eleitoral no caso de constatar-se, quando da interdição, a inaptidão do interditando para exprimir sua vontade.

Ocorre que, caso um determinado sujeito já possua limitação de expressão volitiva antes de completar 16 anos, estar-se-á diante de uma causa de impedimento: este não poderá passar a gozar de direitos políticos, permanecendo os mesmos latentes até eventual alteração na condição da pessoa.

Pode-se imaginar, noutro giro, que um outro indivíduo, já ultrapassada a faixa etária de 16, ou mesmo de 18 anos, alistado e no pleno gozo e exercício de direitos políticos, torne-se incapaz de expressar sua vontade. Nesse caso, a mesma causa se tratará não mais de impedimento, mas sim de privação, na modalidade perda. Nota-se, assim, que os mesmos critérios (como a capacidade de expressar-se) podem repercutir de maneira distinta no campo dos direitos políticos negativos.

Por sua vez, impedem que o cidadão exerça direitos políticos, a ausência de domicílio eleitoral, de alistamento, de atender ao serviço militar obrigatório e a recusa de cumprir 
obrigações a todos imposta. Com efeito, o alistamento é procedimento administrativo sem o qual não se pode integrar os registros públicos de eleitor.

Igualmente, o domicílio eleitoral determinará a localidade de alistamento, sendo condição sine qua non, enquanto o serviço militar obrigatório não atendido, juntamente com a respectiva obrigação alternativa, faz com que aquele que goza de direitos políticos não possa exercê-los.

Esse último caso, que será abordado de maneira específica nos próximos capítulos, encontra previsão no artigo 14 do Texto Constitucional, segundo o qual "§ $2^{\circ}$ Não podem alistar-se como eleitores os estrangeiros e, durante o período do serviço militar obrigatório, os conscritos".

Dentre as restrições aos direitos políticos, tem-se, novamente a idade, afinal, a Constituição bem estabeleceu em seu artigo $14, \S 3^{\circ}$ as idades mínimas como condições de elegibilidade de cada cargo eletivo. Assim que um eleitor menor de 35 aos, embora goze e exerça direitos políticos, suporta uma restrição (uma limitação parcial ao seu exercício), já que não poderá concorrer ao cargo de Presidente da República (a teor da alínea a do dispositivo).

Pelo mesmo motivo, o domicílio eleitoral pode ser visualizado como restrição, já que o cidadão pleno não poderá concorrer a um cargo de circunscrição diversa aquela em que se encontra alistado, o que é estabelecido pelo artigo $9^{\circ}$ da Lei das Eleições (Lei $n^{\circ}$ 9.504/97): "Para concorrer às eleições, o candidato deverá possuir domicílio eleitoral na respectiva circunscrição pelo prazo de seis meses e estar com a filiação deferida pelo partido no mesmo prazo".

Integram ainda as restrições a filiação partidária (outra condição de elegibilidade, que limita, portanto, parcialmente o exercício dos direitos políticos de candidatura); a instrução (ao passo em que o art. 14, $\S 4^{\circ}$ da Carta torna inelegíveis os analfabetos); e a impossibilidade de reeleição dos Prefeitos, Governadores e Presidente (art. 14, § 5º da Lei Maior).

Não bastasse, a incompatibilidade, ou seja, a limitação "à capacidade eleitoral passiva (direito de ser votado), porque o interessado deixou de providenciar seu afastamento temporário ou definitivo dentro do prazo legal" (RAMAYANA, 2018, p. 352) é outra modalidade de restrição. Esse regramento se encontra estabelecido pelo art. $14, \S 6^{\circ}$ do texto constitucional. 
É ainda, restrição aos direitos políticos, o parentesco, já que a Constituição reza:

$\S 7^{\circ}$ São inelegíveis, no território de jurisdição do titular, o cônjuge e os parentes consangüíneos ou afins, até o segundo grau ou por adoção, do Presidente da República, de Governador de Estado ou Território, do Distrito Federal, de Prefeito ou de quem os haja substituído dentro dos seis meses anteriores ao pleito, salvo se já titular de mandato eletivo e candidato à reeleição.

Já o $\$ 8^{\circ}$ traça uma condição sui generis ao militar, a qual será abordado especificamente. Trata-se da imprescindibilidade de que, com a eleição, em sendo o oficial militar candidato, haja o afastamento da ativa da caserna.

Finalmente, as penalidade impostas pela Lei Complementar $\mathrm{n}^{\circ} 64 / 90$, a famigerada Lei de Inelegibilidades, integram o extenso rol de restrições aos direitos políticos, podendo se citar as sanções políticas (art. 1', I, "b" e "c"); as sanções por abuso de poder (art. 1", I, "d" e "h"); a condenação criminal - que também será privação - (art. 1º I, “e”); a rejeição de contas (art. $1^{\circ}$, I, “g” e art. 71, II, da Constituição); a liquidação de estabelecimento de crédito, financiamento ou seguro (art. 1 ', I, “i”); a condenação por ilícitos eleitorais - corrupção eleitoral (art. 299 ou 334 do Código Eleitoral), captação ilícita de sufrágio (art. 41-A da LE), captação ou gastos ilícitos de recursos (art. 30-A e parágrafos da LE), ou condutas vedadas aos agentes públicos em campanhas eleitorais (art. 73 a 75, e 77 da LE) - (art. 1º, I, “j”); renúncia artificiosa (art. 1, I, “k”); improbidade administrativa - que também integrará as privações - (art. 1º I, "l” e Lei $\mathrm{n}^{\circ}$ 8.429/92); infração ético-profissional (art. $1^{\circ}$, I, “m”); desfazimento artificioso do vínculo conjugal (art. $1^{\circ}$, I, “n” e art. 14, $\S 7^{\circ}$ da Carta); demissão do serviço público (art. $1^{\text {o }}$, I, "o"); doação eleitoral ilegal (art. 1º, I, "p" e Lei das Eleições); e, finalmente, a inelegibilidade funcional do membro da magistratura e do ministério público (art. $1^{\circ}$, I, “q”, bem como Leis Complementares 35/1979 e 75/1993).

Cabe também destacar a restrição, prevista pelo mesmo diploma de inelegibilidade, decorrente da declaração de indignidade de oficialato, que atinge os militares condeandos impondo-lhes a impossibilidade de candidatar-se por 8 anos, conforme prevê o artiho $1^{\circ}$, inciso I, alínea “f” da Lei Complementar no 64/90.

Por derradeiro, integram as privações, na modalidade perda, o cancelamento da naturalização (art. 15, I, CF), que faz com que o naturalizado torne-se estrangeiro; e a impossibilidade de exprimir vontade (causa imprópria de privação), quando ocorrer posteriormente ao gozo ou exercício dos direitos políticos. 
Já na modalidade de suspensões, são privações aos direitos políticos a condenação criminal transitada em julgado, a condenação por improbidade administrativa, e a recusa de cumprir obrigação a todos imposta ou prestação alternativa - todas previstas pelo art. 15 da Constituição.

\section{OS DIREITOS POLÍTICOS NEGATIVOS DOS MILITARES NO BRASIL}

Entendida a dinâmica de incidência de direitos políticos negativos na constituição federal, pode-se passar a abordar, especificamente, as repercussões destas aos militares. Como se vê, a mais óbvia limitação se dá com o impedimento (ao exercício) daquele ramo jurídico aos conscritos, mediante a vedação ao alistamento prevista pelo $\S 2^{\circ}$ do artigo 14 da Constituição.

O decreto $\mathrm{n}^{\circ}$ 57.654, de 20 de janeiro de 1966 regulamenta a Lei do Serviço Militar lei $\mathrm{n}^{\circ} 4.375$, de 1964. Em seu artigo $3^{\circ}$, inciso I, item 5, é conceituado o conscrito como "Brasileiros que compõem a classe chamada para a seleção, tendo em vista a prestação do Serviço Militar inicial". Segundo o mesmo dispositivo, classe se refere ao conjunto dos brasileiros "nascidos entre $1^{\circ}$ de janeiro e 31 de dezembro de um mesmo ano".

Portanto, em suma, tratam-se os conscritos do conjunto de cidadãos que participam do processo de seleção para o serviço militar, durante o ano que completarem 18 anos. Conforme se vê, o texto constitucional não impede o exercício dos direitos políticos a todos os conscritos, mas apenas aqueles membros da classe "durante o período de serviço militar obrigatório".

Também por isso a Resolução no 22.097/2005 do Tribunal Superior Eleitoral entendeu que enquanto ainda em curso o prazo para o alistamento militar, não haveria obrigatoriedade de que o alistando fizesse prova dessa quitação.

Integram ainda a classe de conscritos, a teor do que dispõe a Lei nº 5.292 de 1967, “os concluintes dos cursos nos IEs destinados à formação de médicos, farmacêuticos, dentistas e 
veterinários que não tenham prestado o serviço militar inicial obrigatório no momento da convocação de sua classe, por adiamento ou dispensa de incorporação" (art. $4^{\circ}$ ).

Estes devem prestar o serviço militar no ano seguinte ao da conclusão do respectivo curso ou após a realização de programa de residência médica ou pós-graduação, e, durante o período, suportarão também o impedimento político encampado pela Constituição

Ainda no campo das conceituações, aquele que decide voluntariamente prorrogar o período de serviço, denominado engajado ou reengajado, justamente por não prestar "serviço militar obrigatório" estará distanciado do impedimento constitucional.

No entender de José Afonso da Silva, portanto, diversamente dos conscritos, "soldados engajados, cabos, sargentos, suboficiais e oficiais das Forças Armadas e Polícias Militares são obrigados a se alistar como eleitores" (SILVA, 2007, p. 385).

No campo dos direitos políticos, aquele que reúne condições de alistabilidade goza dos mesmos, e, portanto, a vedação ao alistamento trata-se de impedimento ao exercício de tal feixe jurídico. Todavia, pode ocorrer, como visto, que o já alistado (durante o prazo em curso do alistamento militar) posteriormente torne-se conscrito. Igualmente, aos médicos, farmacêuticos, dentistas e veterinários, se já alistados. Uma vez que a previsão Constitucional é a de vedação ao alistamento, questiona-se a repercussão em tais casos.

O posicionamento do Tribunal Superior Eleitoral é o de estender aos já alistados a proibição ao voto. É nesse sentido o estabelecido pelo já distante Resolução n. ${ }^{\circ}$ 20.165, de 07 de abril de 1998:

Uma vez que a Constituição Federal, em seu art. 14, § $2^{\circ}$, estabeleceu vedação aos conscritos para o alistamento eleitoral, pressuposto para a capacidade eleitoral, entendo cabível a manutenção do impedimento do voto aos conscritos já alistados, na forma da reiterada jurisprudência desta Corte.

Igual sentido havia adotado a Resolução n. ${ }^{\circ} 15.850$, de 3 de novembro de 1989, ao tratar daqueles médicos, dentistas, farmacêuticos e veterinários:

Como a Constituição afasta a capacidade eleitoral ativa àquele que está no Serviço Militar Obrigatório, entre eles, o Aluno de Órgão de Formação da Reserva, logo estará afastado do exercício do voto, ainda que eleitor, alistado antes da matrícula no Órgão de Formação. Por essa linha, os médicos, dentistas, farmacêuticos e veterinários que prestam serviço militar inicial obrigatório segundo a Lei n. ${ }^{\circ}$ 5292, de 08 Jul 67, estão também nessa proibição. 
Por um lado, essa posição parece realmente alinhar-se, de maneira mais coerente, ao mandamento constitucional de vedação ao alistamento. Afinal, não seria lógico proibir-se o alistamento do conscrito se não fosse a intenção constitucional de afastá-lo do voto.

Todavia, fica evidenciado um vazio justificativo na imposição desse impedimento. Afinal, quais razões levariam o constituinte (inclusive nas constituições primevas) a encampar essa modalidade de incidência de direitos políticos negativos?

Como se viu, a evolução histórica das normas constitucionais tem imposto drásticas mudanças na recepção cada vez mais alargada daqueles legitimados a tomar parte no pleito. Não foi irrefletida a denominação de "universal" adjetivada ao sufrágio, o que acompanha, inclusive, o processo de proliferação internacional da qualidade de participação política, uma vez que "nas sociedades modernas já não há limites que possam ser impostos - seja pela natureza, seja pela história - contra processos igualitários" (ROSANVALLON, 2010, p. 41).

Olivia Raposo da Silva Telles (2009, p. 18) argumenta que uma das razões para essa adoção é a de proteção à uma noção de neutralidade que deve imperar na tropa. Desse modo, um primeiro argumento seria a necessidade de separar-se o corpo armado do "varejo político".

Uma segunda linha argumentativa em relação à limitação seria a de que a participação ativa no pleito "se contrapõe ao dever de servir às Forças Armadas durante certo tempo, com exclusividade" (NIESS, 1994, p. 40). Também não parece sustentar-se esta noção, pelos mesmos argumentos já explorados, até porque outras categorias também necessárias não encontram óbice algum à tomar parte no sufrágio.

Pior ainda é a extensão pelo Tribunal Superior da proibição do voto aos já alistados. Por mais lógica que seja a aplicação, tratam-se os direitos políticos, como abordado, de direitos fundamentais. Assim espera-se da sua limitação sempre uma imposição restrita. Não é outra a lição de José Afonso da Silva:

O princípio que prevalece é o da plenitude do gozo dos direitos políticos positivos, de votar e ser votado. A pertinência desses direitos ao indivíduo como vimos, é que o erige em cidadão. Sua privação ou a restrição do seu exercício configura exceção àquele princípio. Por conseguinte, a interpretação das normas constitucionais ou complementares relativas aos direitos políticos deve tender à maior compreensão do princípio, deve dirigir-se ao favorecimento do direito de votar e de ser votado, enquanto as regras de privação e restrição hão de entender-se nos limites mais estreitos 
de sua expressão verbal, segundo as boas regras de hermenêutica (SILVA, 2007, p. $385)$.

Todavia, não é essa a única imposição de direitos políticos negativos aos militares, como se viu. Para além do impedimento (ao exercício dos direitos políticos, no caso da norma do art. 14, parágrafo $2^{\circ}$ da $\mathrm{CF}$ ) e da restrição (que se opera quando o Judiciário estende a limitação ao voto aos que já se encontram alistados), outras modalidades de incidência se observam.

Ainda no campo das restrições, ou seja, das normas que parcialmente balizam o exercício daquele ramo jurídico, a Constituição impõe aos militares uma vedação, prevista pelo artigo $142, \S 3^{\circ}$, inciso $\mathrm{V}$, segundo o qual "o militar, enquanto em serviço ativo, não pode estar filiado a partidos políticos".

Como se sabe, a filiação partidária elenca as condições de elegibilidade previstas pelo art. $14, \S 3^{\circ}$, inciso V da Carta. Tem-se, então, esse impasse, consistente na contradição entre ambos as determinações. Os militares passam a possuir, portanto, uma imposição sui generis, anunciada pelo $\S 8^{\circ}$ do art. 14 da Lei Maior:

$\S 8^{\circ} \mathrm{O}$ militar alistável é elegível, atendidas as seguintes condições:

I - se contar menos de dez anos de serviço, deverá afastar-se da atividade;

II - se contar mais de dez anos de serviço, será agregado pela autoridade superior e, se eleito, passará automaticamente, no ato da diplomação, para a inatividade.

O Tribunal Superior Eleitoral respondeu o questionamento na Resolução $\mathrm{n}^{\mathrm{o}}$ 20.993/2002, a qual prevê em seu artigo 14:

$\S 1^{\circ}$ A condição de elegibilidade relativa à filiação partidária contida no art. $14, \S 3^{\circ}$, inciso V, da Constituição da República, não é exigível ao militar da ativa que pretenda concorrer a cargo eletivo, bastando o pedido de registro de candidatura, após prévia escolha em convenção partidária

Em suma, os militares alistáveis (excluídos os conscritos durante o serviço militar obrigatório) poderão candidatar-se. A restrição aos direitos políticos decorrente da filiação partidária, a qual se aplica a todos os candidatos, por sua vez, é mitigada no caso dos integrantes das falanges. Não obstante, o dispositivo constitucional impõe ainda o afastamento ou a passagem à inatividade, a depender do prazo de serviço.

Ainda no campo das restrições aos direitos políticos, há de se abordar a previsão pela Lei Complementar n 64/90 de tornarem-se inelegíveis para qualquer cargo aqueles "os que 
forem declarados indignos do oficialato, ou com ele incompatíveis, pelo prazo de 8 (oito) anos" - conforme art. $1^{\circ}, \mathrm{I}$, "f".

Se convencionou a denominar "indignidade militar" a presente modalidade de inelegibilidade. Conforme elucida José Jairo Gomes (2018, p. 240) trata-se de previsão do artigo 142, $\S 3^{\circ}$, VI, da Constituição Federal, o qual estabelece que a perda de posto e patente "só se dá se o militar for julgado indigno do oficialato ou com ele incompatível. A competência para essa decisão é privativa de Tribunal Militar de caráter permanente, em tempo de paz, ou de Tribunal especial, em tempo de guerra".

Trata-se, portanto, de condenação à qual se encontram sujeitos os membros do oficialato (e não da tropa) das Forças Armadas e das Polícias Militares e Corpos de Bombeiros Militares, quando condenados, a teor do artigo 100 do Código Penal Militar, qualquer que seja a pena, "nos crimes de traição, espionagem ou cobardia, ou em qualquer dos definidos nos arts. 161, 235, 240, 242, 243, 244, 245, 251, 252, 303, 304, 311 e 312”.

Como consequência dessa condenação criminal, pode a competente corte militar impor a indignidade, a qual, por sua vez, acarreta a automática restrição aos direitos políticos, na medida em que o militar em questão estará proibido de candidatar-se

Finalmente, pode-se passar à privação de direitos políticos decorrente da recusa a cumprir obrigação a todos imposta "ou prestação alternativa, nos termos do art. 5\%, VIII", conforme prevê a literalidade do art. 15 da Constituição.

$\mathrm{O}$ aludido dispositivo - o inciso oitavo do artigo $5^{\circ}$ da Carta - brinda-nos com a garantia de que "ninguém será privado de direitos por motivo de crença religiosa ou de convicção filosófica ou política, salvo se as invocar para eximir-se de obrigação legal a todos imposta e recusar-se a cumprir prestação alternativa, fixada em lei”.

Para os fins do presente trabalho, deve se observar que destaca-se como uma daquelas obrigação legalmente imposta a todos a prestação do serviço militar obrigatório, afinal, a própria Constituição impõe em seu artigo 143, § 1º, ser ele "obrigatório nos termos da lei", cabendo às Forças "atribuir serviço alternativo aos que, em tempo de paz, após alistados, alegarem imperativo de consciência, entendendo-se como tal o decorrente de crença religiosa e de convicção filosófica ou política". 
Assim que aquele que, alegando objeção, deixar de cumprir com o serviço militar obrigatório e, concomitantemente, olvidar o cumprimento da prestação alternativa suprida pela Lei $n^{\circ} 8.239 / 91$ se verá face á incidência de direitos políticos negativos, na modalidade privação (já que haverá a supressão integral daqueles direitos), subespécie suspensão (uma vez que a supressão será do exercício, e não do gozo dos direitos políticos - do contrário haveria perda).

Nem se diga que, caso trate-se de sujeito ainda não alistado, e, que, portanto, ainda não exerce direitos políticos, a recusa no cumprimento da prestação alternativa será um impedimento, e não uma privação, ao passo em que proibirá a progressão a dimensão de exercer em matéria de direitos políticos.

\section{INCONSTITUCIONALIDADES NAS PREVISÕES DE DIREITOS POLÍTICOS NEGATIVOS AOS MILITARES}

Ante a radiografia das incidências político-negativas aos militares, pode-se, finalmente, passar-se a uma abordagem da constitucionalidade dessas medidas. Como visto, a mais óbvia das limitações é o impedimento ao alistamento (e ao voto) do conscrito durante o serviço militar obrigatório.

A noção não parece imune de críticas. Por primeiro, e mais obviamente, até em atenção à já mencionada característica universal do sufrágio, as razões que fazem incidir direitos políticos negativos devem possuir inegável justificação. Não parece razoável afasta-se da participação política toda uma classe em razão de tão frágil argumento.

Ainda nessa linha argumentativa, a ideia de que há uma neutralidade cara ao ambiente militar a ser preservada parece conferir à caserna um tratamento distinto. Afinal, se assim fosse, poderia se argumentar em favor da limitação à participação dos próprios servidores da justiça eleitoral no pleito. Afinal, os mesários se encontram em posição tão crítica do ponto de vista da neutralidade quanto as forças armadas em termos de legitimidade. 
Parece se dirigir nesse caminho a crítica de Gilmar Mendes, que, ao tratar do princípio da máxima efetividade promove "um apelo aos realizadores da Constituição para que em toda situação hermenêutica, sobretudo em sede de direitos fundamentais, procurem densificar os seus preceitos, sabidamente abertos" (MENDES, 2007, p. 111).

Igualmente, a disposição constitucional alcança apenas os conscritos, isentando do impedimento aos direitos políticos os oficiais. Pela ótica da neutralidade, essa opção parece ser, em verdade, mais prejudicial, afinal, se há um hipotético temor de utilização político-partidária da tropa, tornar o contingente "inalistável” e garantir aos seus superiores hierárquicos a possibilidade de uma mais profunda participação política não parece lógico.

Também deve se considerar que, em relação à uma suposta ameaça de insurreição motivada por interesses políticos, não parece concebível que a mesma se justifique ou se afaste pelo simples alistamento. Em outras palavras, caso se cogitasse uma identificação partidária tão forte a ponto de justificar o rompimento da rígida hierarquia militar, certamente o mero fato de que o conscrito se encontra impedido de votar não parece ser suficiente para evitá-la.

Como bem observa o Ministro Luís Roberto Barroso (2019, p. 138-139), decorre da rigidez constitucional a necessidade de que que o procedimento de alteração formal do texto passe pela reforma constitucional, o qual poderá ser mais ou menos custoso. Por sua vez, poderá ocorrer, diante da plasticidade das Cartas, a mutação constitucional, ou seja, a modificação do sentido da norma constitucional, sem alteração do texto.

Nesse sentido, para além do poder constituinte originário e derivado, há a prevalência implícita de um "poder constituinte difuso" (BURDEAU, apud BARROSO, 2019, p. 142). Trata-se este da permanente avaliação de constitucionalidade determinadas imposições, exercida por parte do povo, detentor da soberania, mediante intermédio das instituições representativas.

Em evolução, Barroso esclarece serem dois os limites à manifestação da mutação constitucional: as balizas semânticas do texto e as diretrizes fundamentais da Carta constitucional em questão. Se assim não fosse, muito cômodo seria qualquer modificação, no entanto, "se o sentido novo que se quer dar não couber no texto, será necessária a convocação 
do poder constituinte reformador. E se não couber nos princípios fundamentais, será preciso tirar do estado de latência o poder constituinte originário (BARROSO, 2019, p. 142-143).

Diante dessas razões, ainda que se levem em consideração os argumentos no sentido de haver um descompasso no impedimento estendido aos conscritos, não parece haver justificativa para cogitar-se uma mutação constitucional, já que pela literalidade do texto do $\S 2^{\circ}$ do art. 14 da Carta, não parece haver espaço na moldura da norma para qualquer ressignificação.

Igualmente, não prevalece no ordenamento brasileiro, a tese de inconstitucionalidade de normas constitucionais originárias, inclusive em face de cláusulas pétreas ou normas constitucionais superiores.

Esse foi o entendimento consolidado no julgamento da Ação Direta de Inconstitucionalidade $\mathrm{n}^{\circ} 815$, de relatoria do então Ministro Moreira Alves, cujo voto asseverou que o papel de guarda da constituição atribuído ao Supremo Tribunal implica "impedir que se desrespeite a constituição como um todo, e não para, com relação a ela, exercer o papel de fiscal do poder constituinte originário, a fim de verificar se este teria, ou não, violado os princípios de direito suprapositivo".

Deve-se ressaltar, obrigatoriamente, na temática de decretação de inconstitucionalidade de norma originária, a relevância de posicionamentos como o de Otto Bachoff ${ }^{6}$, cujo qual vislumbra a violação a "condicionamentos da ordem do direito natural perante o próprio campo do direito constitucional positivado" (IZOLAN, 2018, p. 1235).

Todavia, a análise da "supraconstitucionalidade" da regra em questão escaparia ao escopo do presente trabalho, demandando metodologia própria e esforço distinto.

Também por isso, embora possa-se discordar do tratamento adotado pelo constituinte aos conscritos, tratamento esse, ressalte-se, já sentido nas Constituições anteriores, não se vislumbra, no atual arranjo constitucional, possibilidade de conceber-se como inconstitucional aquela determinação, seja pela via da modificação informal, seja pela declaração de inconstitucionalidade.

\footnotetext{
${ }^{6}$ Vide a obra Normas Constitucionais Inconstitucionais? Trad. e nota prévia de José Manuel M. Cardoso da Costa. Coimbra: Almedina, 1994.
} 
Quanto à proibição de filiação partidária prevista pelo art. 142, inciso V da Carta, e a respectiva categoria atípica na qual se inserem os militares em razão do $\S 8^{\circ}$ do art. 14, também não parece haver óbice ao reconhecimento da constitucionalidade das restrições.

No primeiro caso, por tratar-se de norma derivada de poder constituinte derivado (inserida pela Emenda Constitucional $n^{\circ} 18$, de 1998), haveria, em tese, a possibilidade de arguição de compatibilidade com o texto originário. Todavia, muito embora trate-se de uma restrição ao exercício dos direitos políticos - consistente na vedação à filiação partidária - não foi obstaculizada a candidatura dos oficiais.

Bem poderia se argumentar que a filiação partidária admite participações democráticas outras que não a mera candidatura, afinal, essa "estrutura intermediária entre a sociedade e o governo" (SARTORI, 2005, p. 21) não tem como único objetivo a ocupação de mandato eletivo, como também a representação, ainda que indiretamente, de interesses dos filiados ou simpatizantes, como se dá, por exemplo, com a legitimação para propor arguições de constitucionalidade.

Ainda assim, não somente aos militares se vedou à participação partidária, sendo já familiar ao ordenamento constitucional brasileiro a noção de que certos ofícios não se coadunam com as facções eleitorais.

Por essa razão, e, especialmente, tendo-se em vista que o mais caro modo de exercer a capacidade política passiva foi preservada (a candidatura, ainda que sem a filiação), não parece ser o caso de se cogitar qualquer inconstitucionalidade.

Por outra ótica, a imposição de que o militar se afaste da atividade obedece à mesma lógica: se é certo que o exercício de oficialato nas forças armadas pressupõe o ônus de não tomar parte nas agremiações partidárias, a candidatura e eventual eleição à cargo político pode derivar ônus, dentre os quais, o afastamento da patente ativa.

A indignidade militar, por sua vez, é causa de restrição aos direitos políticos derivada de norma infraconstitucional (a lei complementar de inelegibilidades). A espécie impõe limitação à possibilidade de candidatura por oito anos daquele julgado indigno do oficialato. 
Quanto à constitucionalidade dessa sanção, não parece haver dúvida quanto à compatibilidade com o texto da Carta de Outubro. Inclusive, o artigo 14 desta previu, expressamente, a delegação à lex complementar da previsão de inelegibilidades:

\begin{abstract}
$\S 9^{\circ}$ Lei complementar estabelecerá outros casos de inelegibilidade e os prazos de sua cessação, a fim de proteger a probidade administrativa, a moralidade para exercício de mandato considerada vida pregressa do candidato, e a normalidade e legitimidade das eleições contra a influência do poder econômico ou o abuso do exercício de função, cargo ou emprego na administração direta ou indireta.
\end{abstract}

Não obstante a crítica à essa noção paternalista de um dever "moralizante" que caberia à Justiça Eleitoral, evidentemente a restrição à candidatura parece se adequar à missão constitucional de proteção do pleito contra abuso no exercício de função na administração, e, portanto, não se vislumbra inconstitucionalidade.

Por outro lado, pode se cogitar a inadequação dessa norma às disposições em tratados internacionais de direitos humanos, ou seja, a sua convencionalidade. Precursor no tema, Mazzuoli esclarece que:

O que se declara (doravante) é a "inconvencionalidade" dessas normas, que podem, até mesmo, continuar sendo "constitucionais" (e muitas vezes são); declara-se a sua incompatibilidade com os direitos (mais benéficos) previstos nos tratados de direitos humanos, ainda que a sua constitucionalidade (menos benéfica) seja integralmente mantida. Tal significa que as leis vigentes - que passaram pelo processo constitucional de elaboração - podem ser declaradas inválidas no Brasil pelo exercício do controle de convencionalidade, quando então é possível declarar inconvencional uma norma sobrevivente ao controle de constitucionalidade (portanto, constitucional). Assim, tem-se uma norma vigente, porém inválida (MAZZUOLI, 2016, p. 172).

Para a aferição do controle de convencionalidade, nenhum mal faz à previsão conter-se em lei complementar, o que não influi em seu status hierárquico. Nessa diapasão, deve-se ter mente a recepção, pelo direito brasileiro, da Convenção Americana de Direitos Humanos, tratado internacional ao qual o Brasil aderiu, ratificando a CADH, em 07 de setembro de 1992.

Dentre as previsões do referido tratado, não se pode olvidar o regramento de direitos políticos (uma vez que já se pontuou, no primeiro tópico, integrarem os direitos fundamentais e humanos). Assim que se fez constar no pacto a previsão, no artigo 23, item 2, que estabelece:

A lei pode regular o exercício dos direitos e oportunidades a que se refere o inciso anterior, exclusivamente por motivos de idade, nacionalidade, residência, idioma, instrução, capacidade civil ou mental, ou condenação, por juiz competente, em processo penal. 
Ora, como fica evidente, não se encontra prevista a oportunidade de regulação de direitos políticos em razão de condenação similar àquela da indignidade militar prevista pela Lei de Inelegibilidades, artigo 1', I, "f". Até porque não se trata de uma condenação "em processo penal", a bem dizer.

Por sua vez, o $\operatorname{artigo~} 5^{\circ}$ da Constituição previu, em seu $\S 2^{\circ}$, que os direitos e garantias “expressos nesta Constituição não excluem outros decorrentes do regime e dos princípios por ela adotados, ou dos tratados internacionais em que a República Federativa do Brasil seja parte”.

Fica evidenciada assim uma opção constituinte, em conformidade com o que se observou também em vizinhos latino-americanos, de incluir no catálogo dos direitos constitucionalmente protegidos aqueles provenientes de pactos internacionais (BORGES; PIOVESAN, 2019, p. 10). Essa opção pode ser consubstanciada, nas palavras de Canotilho, nos seguintes termos:

\begin{abstract}
O programa normativo-constitucional não se pode reduzir, de forma positivística, ao 'texto' da Constituição. Há que densificar, em profundidade, as normas e princípios da constituição, alargando o 'bloco de constitucionalidade' a princípios não escritos, mais ainda reconduzíveis ao programa normativo-constitucional, como formas de densificação ou revelação específicas de princípios ou regras constitucionais positivamente plasmadas (CANOTILHO, 1993, p. 982).
\end{abstract}

É já bem conhecido o entendimento exarado pelo Supremo Tribunal Federal, no sentido de serem equiparadas à constituição apenas as normas provenientes de tratados internacionais que tenham sido recepcionadas pelo rito das emendas constitucionais, previsto pelo artigo $5^{\circ}, \S$ $3^{\circ}$ da Lei Maior.

O presente trabalho discorda dessa posição, compreendendo, como o faz a Doutrina majoritária, que as regras previstas por tratados internacionais de direitos humanos, independentemente do rito de recepção, tratam-se de normas de status materialmente constitucional, a teor do artigo $5^{\circ}, \S 2^{\circ}$, integrando, assim, o bloco de constitucionalidade (MAZZUOLI, 2015, p. 226).

De um lado, essa recepção de norma internacional com hierarquia constitucional levaria à inconstitucionalidade da restrição de direitos políticos em razão da declaração de indignidade de oficialato. Por outra luz, retomando-se os argumentos que justificaram considerar-se constitucional o impedimento ao alistamento do conscrito, haveria uma colisão entre normas 
de hierarquia constitucional - aquela do artigo $14, \S 2^{\circ}$, e aquela advinda da Convenção Americana.

Por derradeiro, deve-se abordar a compatibilidade da modalidade de incidência de direitos políticos negativos aquele que deixa de cumprir o serviço militar obrigatório, e, concomitantemente, prestação alternativa.

Essa limitação, que, como já abordado, pode tratar-se de privação ou de impedimento (a depender se aquele que a suporta já se encontrava alistado quando da negativa), acabou por ser regulada pela Lei no 8.239/91, e pela Portaria nº 2.681/1992 da Comissão do Serviço Militar.

A rigor, trata-se de limitação de direitos políticos prevista por norma oriunda de poder constituinte originário, de modo que, para além dos questionamentos já delineados, não haveria de se cogitar a inconstitucionalidade sem escapar aos limites do presente trabalho.

Todavia, quanto à mencionada Portaria, há de se apontar que o texto definiu a duração do serviço alternativo, nos seguintes termos: “Art. 50 A obrigação para com o Serviço Alternativo, em tempo de paz, começa a partir da opção do alistado por este Serviço e subsistirá até 31 de dezembro do ano em que completar 45 (quarenta e cinco) anos".

Assim há de se questionar a situação em que se inserirá aquele maior de 45 anos, que deixar de prestar o serviço militar obrigatório. Ora, como se viu, os conscritos tratam-se não somente daqueles que, mediante faixa etária, fazem jus ao alistamento militar, como também aos médicos, farmacêuticos, dentistas e veterinários que não tenham prestado o serviço militar inicial.

Em qualquer dos casos, pode se cogitar, hipoteticamente, situações em que o critério estabelecido pela Portaria seja ultrapassado, mediante a ausência de cumprimento, por parte do conscrito, ao cumprimento do serviço alternativo.

Portanto, ao estabelecer-se um limite temporal a partir do qual a prestação sem a qual os direitos políticos deixam de ser restabelecidos, a norma deixa de dizer respeito a uma suspensão, afinal, essa modalidade de privação se caracteriza pela limitação temporária do exercício dos direitos políticos. 
Por sua vez, também não se trata da outra modalidade válida de privação, a perda, já que a perda de direitos políticos, embora atinja o gozo destes e seja definitiva, se caracteriza pela possibilidade de retomada - é o caso do cancelamento de naturalização.

Pode se concluir, assim, que o artigo $5^{\circ}$ da Portaria $n^{\circ} 2.681 / 1992$ só pode ser interpretado de duas maneiras: ou, após aquele a quem incide os direitos políticos negativos atingir 45 anos de idade sem o cumprimento do serviço alternativo, deixa de se impor a suspensão, restabelecendo-se de imediato o exercício da participação política.

Ou, em uma segunda possibilidade, essa norma deve se classificar como cassação de direitos políticos - hipótese de privação que não admite o restabelecimento, o que caracteriza essa limitação como evidentemente inconstitucional.

\section{CONCLUSÃO}

Como se vê, o papel das forças armadas na estrutura política não se apresenta imune de inconvenientes. Em um histórico constitucional repleto de rupturas institucionais nas quais, em todos os casos, os militares ocuparam papel de destaque, não é de se espantar a ocorrência de incongruências no tratamento das possibilidades de participação política dessa classe.

Não bastasse, no campo do exercício dos direitos políticos, impera em geral uma baixa densificação dos conceitos e uma ausência na definição exata dos institutos jurídicos que repercutem na participação dos cidadãos. Assim, quanto aos membros das falanges armadas, acumularam-se fatores que contribuíram a um trato normativo descuidado, para dizer o mínimo.

Esses apontados déficits têm levado a um tratamento por vezes inadequado dos direitos políticos, e, certamente, incompatível com o alto grau de afetação à normalidade democrática que desempenha aquele ramo. Para confirmar essa afirmação, basta notar que o próprio texto constitucional não cuidou de distinguir algumas das incidências de direitos políticos negativos, tais como perda e suspensão. 
Não por outra razão, o presente trabalho entendeu pela necessidade de estabelecer, $a$ priori, os conceitos e limites que seriam utilizados na avaliação da constitucionalidade das normas que repercutissem às garantias políticas dos militares. Com efeito, a fim de que se viabilizasse a comparação de uma regra política com os preceitos da Carta, antes se fez primordial a avaliação das características e delimitações dessas regras.

Assim que o presente trabalho passou a classificar em três modalidades as incidências de direitos políticos negativos: os impedimentos (que impossibilitam o gozo ou o exercício daquele feixe); as restrições, que limitam parcialmente o exercício, em algum de seus aspectos; e as privações, que se subdividem em suspensão (supressão total do exercício), perda (supressão total do gozo e exercício), e cassação (subespécie inconstitucional onde há a supressão total do gozo e exercício, mas sem a possibilidade de reobtenção).

Diante dessas características, as mais expressivas imposições de direitos políticos negativos aos membros das forças armadas puderam ser classificadas, para, assim, verificar-se a sua compatibilidade com a constituição. Nessa aferição de constitucionalidade utilizaram-se os posicionamentos dominantes na jurisprudência e na academia brasileira.

Por esse critério, a primeira das limitações, qual seja, o impedimento ao voto do conscrito se vislumbra constitucional, embora possa se considerar equivocada a determinação (por violar a noção de universalidade do sufrágio), trata-se de norma de poder constituinte originária, a respeito da qual não se vislumbrou viabilidade de mutação constitucional, e cuja declaração de inconstitucionalidade escaparia à previsão admitida pela jurisprudência nacional.

O mesmo não pode ser dito do impedimento ao voto dos conscritos já alistados, encampada pelo Tribunal Superior Eleitoral. Quanto a esta, embora coerente com o sentido da norma constitucional do artigo 14 , parágrafo $2^{\circ}$, não há como se cogitar uma imposição negativa de direitos políticos sem a expressa previsão em lei ou em norma supralegal, restando, assim, inconstitucional.

Quanto à vedação à filiação partidária do militar, não se vislumbra inconstitucionalidade, ao passo em que a garantia de candidatura foi preservada, desde que, nos termos do parágrafo $8^{\circ}$ do artigo 14 da Carta, seja o Oficial afastado da ativa. 
Por sua vez também compatível com a Constituição, em termos estritos, a previsão de imposição de restrição aos direitos políticos de elegibilidade daquele oficial condenado às penas de indignidade militar, prevista pela Lei Complementar nº 64/1990.

Todavia, ressaltou-se também que essa previsão é incompatível com o acervo de direitos políticos da Convenção Americana de Direitos Humanos. Portanto, pode-se conceituar essa restrição como, concomitantemente, constitucional e inconvencional. Tem-se, assim, uma norma de tratado de direito internacional de direitos humanos, a qual, segundo a doutrina brasileira, integra materialmente o bloco constitucional, que veda a determinação da Lei Complementar.

Uma vez que o artigo 14 da Constituição, em seu parágrafo nono, somente estabelece à lex a atribuição de definir critérios de inelegibilidade para proteger a moralidade, sem, contudo, apontar taxativamente quais seriam esses critérios, não há contrariedade entre a norma da Carta e a da Convenção, mas, somente, entre a da Lei Complementar e a CADH. Ao fim e ao cabo, pode-se considerar inconvencional, e, portanto, invalida a norma, muito embora constitucional.

Finalmente, pode ser verificada a constitucionalidade da norma do artigo 15 da Constituição que prevê a privação de direitos políticos àquele que se recusa a cumprir obrigação a todos imposta. Tanto essa limitação quanto aquela que incide sobre a proibição de alistamento do conscrito são normas de poder constituinte originário, e, assim, a resposta ao conflito aparentemente delas decorrente com a sistemática interamericana de proteção aos direitos humanos escaparia à presente abordagem.

Por sua vez, na hipótese daquele que já tiver completado quarenta e cinco anos, e que, portanto, não se encontra mais contemplado pela possibilidade de prestação de serviço alternativo ao serviço militar obrigatório, a privação de direitos políticos em caso de objeção de consciência se transporia de suspensão para cassação - já que não admitiria retomada dos direitos de que o sujeito se viu privado - o que infirma a inconstitucionalidade dessa previsão.

Ante o exposto, parece bastante claro haver a necessidade de uma ressignificação dos conceitos afetos a matéria dos direitos políticos, justamente de modo a melhor delimitarem-se sua área de influência. Sem essa densificação, eterniza-se o risco de tratamento casuístico em ramo por demais relevante à normalidade democrática. 
Igualmente, as disposições introduzidas pela Convenção Americana de Direitos Humanos, quase 30 anos após sua recepção ainda encontram resistência na sua efetiva aplicação, enquanto se encontram, aparentemente, bastante distantes de várias das determinações nacionais, em especial aquelas da Lei de Inelegibilidades.

Essa compreensão adequada e profunda dos limites e significações dos diversos fatores que compõem o regramento aos direitos políticos, bem como a maturação e avaliação das próprias previsões constitucionais, são fatores essenciais para a melhor adequação da sistemática que envolve os processos de deliberação eleitoral brasileira, notadamente, na sua relação com os membros das forças armadas.

\section{REFERÊNCIAS BIBLIOGRÁFICAS}

BARBOSA, Leonardo Augusto de Andrade. The ballot under the bayonet: election law in the first years of the Brazilian civil-military regime (1964-1967). Revista direito GV, São Paulo, v. 13, n. 1, p. 145-170, Apr. 2017.

BARBOSA, Ruy. Memória sobre a eleição presidencial, In: Obras completas de Ruy Barbosa. Rio de Janeiro: Ministério da Educação e Cultura, 1971.

BARROSO, Luís Roberto. Curso de Direito Constitucional Contemporâneo. $8^{\mathrm{a}}$ ed. São Paulo: Saraiva, 2019.

BERCOVICI, Gilberto. O poder constituinte do povo no Brasil: um roteiro de pesquisa sobre a crise constituinte. Lua Nova, São Paulo, 88: 305-325, 2013.

BORGES, Bruno Barbosa; PIOVESAN, Flávia. O diálogo inevitável interamericano e a construção do ius constitutionale commune. Revista direitos fundamentais e democracia, v. 24, n. 3, p. 5-26, set./dez. 2019.

BUENO, José Antônio Pimenta. Marquês de São Vicente. Organização e introdução de Eduardo Kugelmas - São Paulo: Ed. 34, 2002.

BURDEAU, Georges. Traité de Science politique: le statut du pouvoir dans 1'État. 2 ed., t. 4. Paris: LGDJ, 1969.

CANOTILHO, Jose Joaquim Gomes. Direito Constitucional e Teoria da Constituição. $6^{\mathrm{a}}$ ed. Editora Almedina. 1993

CARVALHO, Eder Aparecido de; GILENO, Carlos Henrique. Reflexões sobre o Poder Moderador nas instituições políticas brasileiras: o pretérito e o presente. Revista Em Tese, v. 15, n. 1 (parte II), p.10-32, mar./abr., 2018. 
GOMES, José Jairo. Direito eleitoral. 14ª ed. São Paulo: Atlas, 2018.

KAZMIERCZAK, Luiz Fernando; ALVES, Fernando de Brito. O orçamento participativo como forma de exercício dos direitos políticos. Espaço Jurídico Journal of Law. v. 14, n. 2, p. 417-436, jul./dez. 2013. P. 417-435.

LIMA, Flávia Santiago. Jurisdição constitucional e política: ativismo e autocontenção no STF. Curitiba: Juruá, 2014.

MACHADO, Marcelo Forneiro. A evolução do conceito de soberania e a análise de suas problemáticas interna e externa. 2009. 163 f. Dissertação (Mestrado em Direito) - Pontifícia Universidade Católica de São Paulo, São Paulo, 2009.

MANIN, Bernard. The Principles of Representative Government. Cambridge University Press, 2002.

MAZZUOLI, Valerio de Oliveira. O estado da arte da aplicação do direito internacional público no Brasil no alvorecer do século XXI. Direito Público (Porto Alegre), v. 13, p. 162-192, 2016.

MAZZUOLI, Valerio de Oliveira. Podem os Tratados de Direitos Humanos Não "Equivalentes" às Emendas Constitucionais Servir de Paradigma ao Controle Concentrado de Convencionalidade? RDU, Porto Alegre, Volume 12, n. 64, 2015, 222-229, jul-ago 2015

MENDES, Gilmar. Curso de Direito Constitucional. São Paulo: Saraiva/Instituto Brasiliense de Direito Público, 2007.

MOTA, Carlos Guilherme. História de um silêncio: a guerra contra o Paraguai (1864-1870) 130 anos depois. Estudos Avançados, São Paulo, v. 9, n. 24, p. 243-254, Ago. 1995. Disponível em: $<$ http://www.scielo.br/scielo.php?script=sci_arttext\&pid=S0103-

$40141995000200012 \& \operatorname{lng}=\mathrm{en} \& n r m=\mathrm{iso}>$. Acesso em 08 jul. de 2020.

NIESS, Pedro Henrique Távora. Condições de elegibilidade e inelegibilidades. São Paulo: Saraiva, 1994.

QUEIROZ, Luiz Viana. Direitos políticos como direitos humanos: impacto no Direito Eleitoral brasileiro da Incorporação da Convenção Americana de Direitos Humanos. 2002. Dissertação (Mestrado). Programa de Pós-Graduação em Direito, Universidade Federal de Pernambuco, Recife, 2002.RAMOS, André de Carvalho. Curso de Direitos Humanos. $4^{\mathrm{a}}$ ed. São Paulo: Saraiva, 2017.

ROSANVALlON, Pierre. Democratic Legitimacy: Impartiality, Reflexivity, Proximity. Oxford: Princeton University Press, 2011.

ROSANVALLON, Pierre. Por uma história do político. São Paulo: Alameda, 2010.

SARTORI, Giovanni. Parties and party systems. Colchester: European Consortium for Political Research (ECPR) Press, 2005. 
SILVA, José Afonso da. Curso de Direito Constitucional Positivo. $28^{\mathrm{a}}$ ed. São Paulo: Malheiros, 2007.

TELLES, Olivia Raposo da Silva. Direito eleitoral comparado: Brasil, EUA e França. São Paulo: Saraiva, 2009.

VAINER, Bruno Zilberman. Breve histórico acerca das Constituições do Brasil e do controle de constitucionalidade brasileiro. Revista Brasileira de Direito Constitucional - RBDC, n. $16-$ jul./dez. 2010.

Data de Submissão: 18/01/2021

Data de Aceite: 03/04/2021 